\title{
RECENZJE
}

Klio. Czasopismo poświęcone dziejom Polski i powszechnym PL ISSN 1643-8191, t. 46 (3)/2018, s. 185-220

\section{Trucizny, trucicielki i truciciele. Medyczne i kulturowe aspekty trucia na przestrzeni dziejów, red. Walentyna Korpalska, Wojciech Ślusarczyk, Roksana Wilczyńska, Wydawnictwo Collegium Medicum im. Ludwika Rydygiera, Bydgoszcz 2017, ISBN 978-83-946672-4-5, s. 252}

rucizny i ich działanie od dawna cieszą się zainteresowaniem przedsta-
wicieli różnych dyscyplin naukowych. Potwierdza to nawet pobieżny
przegląd bibliografii prac poświęconych substancjom toksycznym z ostat-
nich kilku lat ${ }^{1}$. Po publikacje na ten temat sięgają nie tylko specjaliści, ale

1 Zob. M. Ciechomska, Maści czarownic, śmiertelne trucizny i serum prawdy: historia i wykorzystanie psychoaktywnych roślin z rodziny solanacea, „Zeszyty Naukowe Towarzystwa Doktorantów UJ. Nauki Ścisłe” 2014, Nr 2 (9), s. 19-34; A. Ryś, B. Siek, Między tekstem medycznym, historycznym i dramatycznym - „aipa vav@ov” jako trucizna, w: Inter textus, miedzy tekstami, red. Z. Głombiowska, Gdańsk 2013, „Studia Classica et Neolatina”, nr 10, s. 63-68; P. Lampkowska, Kilka stów o antidotach stosowanych w starożytności, „Studia Europaea Gnesnensia” 2011, nr 3, s. 211-226; O. Błyskal, Nulla res tam necessaria est omni generi hominum quam medicina. O medycynie, lekarzach i rzymskich szpitalach wojskowych w I-III w., „Annales Universitatis Paedagogicae Cracoviensis. Studia Historica” 2009, nr 8, 
też czytelnicy spragnieni sensacji oraz wielbiciele literatury kryminalnej. Nic dziwnego, bo książki o zatruciach, niezależnie od ujęcia czy przyjętej metodologii, czyta się czasami jak dobry kryminał. Mimo że celowe otrucie przestało już być główną przyczyną śmierci w wyniku spożycia toksyn wyparte zostało przez zatrucia wypadkowe - ciaggle słyszy się o takich incydentach, jak zbrodnicze zastosowanie radioaktywnego polonu-210 w celu pozbawienia życia Aleksandra Litwinienki ${ }^{2}$. Tematyka ta nadal stanowi wyzwanie dla wielu środowisk naukowych - od farmaceutów i lekarzy, przez historyków czy literaturoznawców, aż po prawników.

Omawiany tom to recenzowana monografia wieloautorska, zawierająca 19 rozprawek (nazywanych konsekwentnie rozdziałami) poprzedzonych wstępem, w którym redaktorzy przybliżają okoliczności powstania publikacji. Jak się dowiadujemy, jest ona pokłosiem konferencji, zorganizowanej w kwietniu 2016 roku przez Studenckie Koło Naukowe Historii Medycyny i Farmacji, działające przy Zakładzie Historii Medycyny i Pielęgniarstwa Collegium Medicum im. Ludwika Rydygiera Uniwersytetu Mikołaja Kopernika. Wzięli w niej udział głównie młodzi badacze i ich opiekunowie (będący też w kilku przypadkach współautorami tekstów, co jest powszechną praktyką w środowiskach uniwersytetów medycznych ${ }^{3}$ ), reprezentujący - jak wynika z alfabetycznego wykazu autorów, umieszczonego na końcu książki - różne dyscypliny i ośrodki naukowe (Uniwersytet Mikołaja Kopernika w Toruniu, Uniwersytet Kazimierza Wielkiego w Bydgoszczy, Uniwersytet Medyczny we Wrocławiu, Uniwersytet Warmińsko-Mazurski w Olsztynie, Uniwersytet Adama Mickiewicza w Poznaniu, Uniwersytet Zielonogórski, Collegium Da Vinci w Poznaniu i Ewangelikalna Wyższa Szkoła Teologiczna we Wrocławiu). Poza nielicznymi wyjątkami (Radosław Łazarz, Niebezpieczeństwo btędu metodologicznego. Symboliczna interpretacja

s. 38-54 (o trucicielstwie s. 42-43); A. Gawliński, Zbrodnicze otrucie - przegląd kryminalistyczno-historyczny, „Przegląd Prawniczy, Ekonomiczny i Społeczny” 2014, nr 1, s. 32-43; E. Jaszczak, S. Narkowicz, J. Namieśnik, Ż. Polkowska, Amigdalina: lek przeciwnowotworowy czy trucizna?, „Analityka: nauka i praktyka” 2017, nr 2, s. 64-67; K. Kulik-Kupka, A. Koszowska, A. Brończyk-Puzoń, J. Nowak, K. Gwizdek, B. Zubelewicz-Szkodzińska, Arsen - trucizna czy lek?, „Medycyna Pracy” 2016, t. 67, nr 1, s. 89-96.

${ }^{2}$ Zob. A. Gawliński, op. cit., s. 43.

${ }^{3}$ Ewa Sawicka jest współautorką aż pięciu rozdziałów. 
trucizny $w$ pismach Michata Sędziwoja) autorzy nie zajmują się ujęciami metaforycznymi, koncentrując się na dosłownym znaczeniu słowa „truć” W kręgu ich zainteresowania znalazły się kwestie związane z pochodzeniem i dawkowaniem trucizn, leczniczym, zbrodniczym i nieetycznym wykorzystywaniem toksycznych substancji oraz ich miejscem i funkcją w dziełach artystycznych i literackich. Autorzy przywołują głośne przypadki umyślnych i nieumyślnych zatruć, dostrzegając w truciźnie środek do zdobycia miłości, pieniędzy i władzy. Książka ma zatem charakter interdyscyplinarny. Tematykę zapowiada już okładka, korespondująca z zawartością monografii: umieszczono na niej ilustrację, wyobrażającą osiemnastowieczną apteczną szafę na trucizny ${ }^{5}$. Adekwatny do zawartości jest też tytuł publikacji.

Tak szeroko zakreślony temat pracy zbiorowej może stanowić zagrożenia dla jej wewnętrznej spójności i merytoryczności. W omawianym tomie wyraźne dominuje nachylenie historyczne, co nie budzi zdziwienia z dwóch powodów: po pierwsze, trucicielstwo było procederem bardzo rozpowszechnionym aż do XIX w., kiedy to pojawiły się inne zagrożenia oraz sposoby pozbywania się niewygodnych osób, po drugie, pomysłodawcy publikacji reprezentują środowisko historyków medycyny. Redaktorzy tomu nie zdecydowali się na wewnętrzne podziały, nie mamy zatem w nim żadnych segmentów tematycznych czy związanych z dyscypliną badawczą. Materiał prezentowany jest w układzie chronologiczno-problemowym. Jak zapowiadają redaktorzy, chodzi bowiem o „prześledzenie zmian w postrzeganiu i stosowaniu oraz sposobie przybieranych form i używaniu trucizn” (s. 7).

Swoistym wprowadzeniem do tomu stają się słowa Paracelsusa „Cóż jest trucizną? Wszystko jest trucizną i nic nie jest trucizną. Tylko dawka czyni, że dana substancja nie jest trucizną”, wyznaczające zarazem pole terminologiczne i obszar rozważań autorów tekstów: za truciznę uznana zostaje „każda substancja, która w odpowiedniej dawce jest w stanie wywołać

${ }^{4}$ Zgodnie z obowiązującą współcześnie definicją, trucizna jest to substancja, egzogenna lub endogenna, która powoduje zaburzenie funkcji organizmu lub jego śmierć. Pojęcie trucizny często stosujemy wymiennie z pojęciem ksenobiotyk, oznaczającym substancję obcą dla organizmu. Por. T. Marcinkowski, Medycyna sądowa dla prawników, Szczytno 2010, s. 379.

${ }^{5}$ Eksponat Muzeum Farmacji Collegium Medicum Uniwersytetu Jagiellońskiego. 
efekt fizjologiczny w organizmie człowieka” (s. 7). Lektura całości pokazuje, że nie ma substancji zupełnie obojętnych dla organizmu człowieka, a więc całkowicie nietoksycznych. Obecnie wiemy, że oprócz dawki również inne czynniki mogą mieć wpływ na toksyczność danego preparatu. Do czynników tych należy zaliczyć drogę wchłaniania substancji toksycznej, częstość jej zażywania, czas trwania ekspozycji i zakres uszkodzeń wywołany przez truciznę.

Przedmiotem dociekań autorów jest literatura wysokoartystyczna i popularna, teksty użytkowe, specjalistyczne oraz dzieła filmowe. Autorzy sięgają też do zasobów Internetu. To walor i jednocześnie największa słabość publikacji. Wykorzystanie różnego typu źródeł, nie zawsze odpowiednio opisanych, powoduje, że straciła ona charakter stricte naukowy. Lektura całości przynosi refleksję, że mamy do czynienia ze zbiorem nierównym pod względem merytorycznym i językowo-stylistycznym. Należy zgodzić się z redaktorami tomu, że niektóre artykuły mają charakter przyczynkarski i mogą budzić niedosyt (s. 10). Nie wnoszą do stanu badań nic nowego, stanowiąc kompilację ogłoszonych wcześniej prac. Oprócz nich odnajdziemy w księdze rozprawy, które posiadają walory poznawcze, oraz takie, które zachęcą do podejmowania dalszych badań.

Pierwsze dwa artykuły przynoszą informacje o truciznach w świecie grecko-rzymskiego antyku. Adam Zemełka (Trucizny i odtrutki w antycznej Helladzie - mitologia, literatura, historia) prezentuje substancje toksyczne i antidota w starożytnej Grecji a Tomasz Dreikopel („Modus operandi” trucicieli w „Rocznikach” Tacyta oraz „Żywotach cezarów” Swetoniusza) sposób działania trucicieli w Rzymie. Rozdziały te, oparte głównie o źródła historyczne i literackie (dzieła Homera, Owidiusza, Sofoklesa, Plutarcha, Tacyta, Swetoniusza) zarysowują kontekst kulturowy dla rozważań, zawartych w dalszej części tomu (antyczne archetypy trucicielek i trucicieli, związek trucizn z zabobonem i magią erotyczną, popularność eliksirów miłosnych i afrodyzjaków, motywacja zbrodniarzy i metody ich działania). Autorzy rozpraw stworzyli nie tylko bogatą galerię ofiar i sprawców (a właściwie sprawczyń, bo zbrodnicze otrucia wydają się być domeną kobiet), ale próbowali też dociec, jakie substancje wykorzystywano w starożytności do sporządzania trucizn oraz antidotów. Dwa kolejne rozdziały, poświęcone morderstwom politycznym (Justyna E. Białowąs, Trucizna $i$ truciciele $w$ rodzie 
Piastów oraz Artur Wesołowski i Ewa Sawicka, Królowe trucicielki. Trucizna w stużbie kobiet na dworach królewskich Europy) potwierdzają długo utrzymująca się w kulturze tendencję do tłumaczenia użyciem trucizny wszelkich nagłych zgonów w rodach panujących. Do szkicu Wesołowskiego i Sawickiej mam pewną uwagę - należałoby podkreślić, być może już w tytule, że ich ustalenia odnoszą się do wizji artystycznej, rozdział jest bowiem oparty głównie na beletrystyce, legendach i niezweryfikowanych przekazach ustnych. Autorzy przywołują m.in. powieści historyczne Maurice'a Druona Królowie przeklęci oraz Królowa Margot Aleksandra Dumasa. Nie jest zatem możliwe ustalenie, czy zaprezentowane w szkicu historie „oparte są chociaż po części na prawdziwych wydarzeniach, czy też należy je traktować z przymrużeniem oka” (s. 49). Pojawia się w nim jednak kwestia, która znajdzie kontynuację $\mathrm{w}$ następnych rozdziałach, a mianowicie przypisywanie kobietom szczególnego upodobania do zbrodniczego używania trucizn. Substancje toksycznie niejednokrotnie pozwalały im na zaznaczenie swej obecności w strefie publicznej, zarezerwowanej w kulturze patriarchalnej dla mężczyzn. Dzięki truciźnie mogły współdecydować nie tylko o przyszłości swojej rodziny, ale także państwa (Mahaut d'Artois, Bona Sforza). Szkic „historyczno-prawny” Pawła M. Modrzyńskiego (Otrucie w prawodawstwie miast polskich i pruskich doby późnego średniowiecza i odrodzenia na tle ogólnoeuropejskim), dotyczy między innymi problemu łączenia w tradycji prawnej trucicielstwa z czarami, wedle powszechnego przekonania uprawianymi głównie przez kobiety, oraz narodowością, religią i statusem społecznym podejrzanych ${ }^{6}$. Ofiarami tych stereotypów padali głównie Żydzi i uważani za wirtuozów trucia Włosi.

Ciekawie prezentują się ustalenia Daniela Dzieniesiewicza, Filipa Gralińskiego i Piotra Wierzchonia (Śledztwo lingwochronologizacyjno-fotodokumentacyjne: o truciu w polskim piśmiennictwie XIX i XX wieku), którzy skupili się na wybranych aspektach ewolucji polskiego słownictwa związanego z tematyką trucizn. Wydaje mi się, że rozdział ten, mimo właściwego osadzenia w ciągu chronologicznym, ze względu na specyfikę prezentowanego materiału powinien otwierać cały tom. Dociekania lingwistycz-

${ }^{6}$ Por. B. P. Levack, Polowanie na czarownice w Europie wczesnonowożytnej, przeł. E. Rutkowski, Wrocław 2009, s. 187-188. 
ne dobrze wpisują się w tematykę toksykologiczną, dowodząc, że wiedza kulturowa pozostaje w ścisłej relacji z wiedzą językową. Najważniejszym wnioskiem z przeprowadzonych badań jest wskazanie stopniowej tendencji do metaforyzacji leksemów z rdzeniem "truć” oraz ich występowania jako komponentów związków wyrazowych. Wyraz „truciciel” coraz rzadziej używany jest w znaczeniu dosłownym, zastępują go użycia metaforyczne: częściej trujemy „komuś głowę” niż ludzi. Trzy kolejne rozdziały (Dominik Babis, Historia arszeniku - od mordercy do uzdrowiciela, Joanna Roik i Ewa Sawicka Flour - pomaga czy truje?, Kamil Guzy i Ewa Sawicka, Truciciel zawieszony w powietrzu) uświadamiają czytelnika, że trucizny znajdowały i znajdują w dalszym ciągu wiele zastosowań, aplikowane w odpowiednich porcjach są nie tylko bezpieczne, ale i pożyteczne. Autorzy ujawniają nieznane szerzej fakty „z życia” arszeniku i fluoru i zwracają uwagę na zanieczyszczenie atmosfery - daninę składaną cywilizacji. Ponownie okazuje się, że granica między dawką toksyczną a terapeutyczną jest niewielka i że ciągle pojawiają się nowe zagrożenia (smog). Z recenzenckiego obowiązku muszą nadmienić, ze niektóre sądy a nawet cytaty nie zostały tu dostatecznie osadzone w przypisach (przykładowo s.130, wers 2-4 od dołu).

Przykład tekstu Arkadiusza Woźniaka i Ewy Sawickiej, Wtosy jako materiat badawczy $w$ badaniach toksykologicznych "post factum" $i$ "post mortem" po raz kolejny pokazuje, że dla niektórych rozdziałów nie jest łatwo znaleźć odpowiednie miejsce w monografii. Moim zdaniem jego lokalizacja rozbija ciąg wypowiedzi o substancjach toksycznych, które mogą leczyć i pomagać. Może lepszym sąsiedztwem byłby rozdział poświęcony Agacie Christie? ${ }^{7}$

Następne teksty wychodzą poza obręb rozważań literaturoznawczych. Ich głównym założeniem jest zaprezentowanie różnorodnych właściwości substancji, wykorzystywanych w przemyśle spożywczym, farmaceutycznym czy kosmetycznym. Uzmysławiają czytelnikowi, że we współczesnym świecie w otoczeniu człowieka występuje kilkanaście milionów związków o potencjalnie toksycznym działaniu. Są to produkty roślinne, zwierzęce

7 Autor przywołuje m. in. przypadek Ludwika van Beethovena, Napoleona i pochodzącej z Chile mumii. 
i preparaty chemiczne, do których dostęp jest bardzo szeroki i swobodny. Do tej grupy rozdziałów należą teksty: Emilii Pierzchały „Co za duzo, to nie zdrowo" (czy nie zakradła się tu literówka i nie powinno być „Co za dużo, to niezdrowo'?), Karoliny Dydak i Marioli Śliwińskiej-Mossoń Niejadalne rośliny egzotyczne, Adrianny Boińskiej i Marioli Śliwińskiej-Mossoń Rośliny na talerzu - jadalne czy niebezpieczne dla zdrowia oraz Katarzyny Kempki i Piotra Kamińskiego Trucizny też rosna na grzadkach.

Ostatnie cztery rozdziały ponownie wprowadzają czytelnika w przestrzeń literatury. Marta Grandke zajmuje się truciznami, eliksirami i napojami magicznymi w powieściach fantasy Andrzeja Sapkowskiego. Martyna Szydełko i Ewa Sawicka przedstawia Agatę Christie jako ekspertkę od trucizn, natomiast Sylwia Florczak i Piotr Kamiński próbują odpowiedzieć na pytanie, skąd bierze się niezwykła popularność literatury postapokaliptycznej. Rozdziały te nie są wolne od mankamentów. Wymagają korekt stylistycznych i uzupełnienia źródeł informacji albo - tam, gdzie źródła się pojawiają - dodania numerów stron (rozdział o Christie, zwłaszcza jego zakończenie, w którym pojawia się teza o instruktażowym charakterze powieści „królowej kryminału”, przydatnych zarówno przy planowaniu morderstw, jak i ratowaniu zatrutych osób). Monografię domyka obszerny rozdział Jędrzeja Baszyńskiego i Piotra Kamińskiego Uzależnienie uchwycone $w$ kadrze. Różne oblicze natogu w kinematografi amerykańskiej oraz najnowszej kinematografi polskiej - analiza wybranych przyktadów. Rozważania o ambicjach komparatystycznych budzą ciekawość, jednak w artykule poświęconym w całości analizie dzieł filmowych razi nadmierne korzystanie z witryn internetowych ze streszczeniami ich fabuł. Rodzi to wrażenie, że tekst nie przynosi oryginalnych rozpoznań, ale przegląd zgrabnie zreferowanej literatury przedmiotu. Sami autorzy rozdziału recenzują swoje poczynania bardzo pochlebnie, pisząc między innymi o „przeprowadzeniu wyczerpującej analizy wybranych przykładów pod względem treści i okoliczności powstania i osiągnięciu celu nadrzędnego, mianowicie zaprezentowaniu odmiennych podejść do tematyki nałogu na ekranie" (s. 222).

Reasumując, należy stwierdzić, że mimo wskazanym mankamentów i zastrzeżeń, recenzowana książka posiada walory poznawcze. Uświadamia, że pewne tematy warto badać interdyscyplinarnie, i choć zasadniczo nie 